\title{
Invasion of Rosa rugosa (Rugosa Rose) into Coastal Plant Communities of Brier Island, Nova Scotia
}

\author{
David J. Garbary ${ }^{1, *}$, Nicholas M. Hill ${ }^{2}$, and Anthony G. Miller ${ }^{1}$ \\ ${ }^{1}$ Department of Biology, St. Francis Xavier University, Antigonish, Nova Scotia B2G 2W5 Canada \\ ${ }^{2}$ Fern Hill Institute of Plant Conservation, 424 Bentley Road, South Berwick, Nova Scotia B0P 1E0 Canada \\ ${ }^{*}$ Corresponding author; email: dgarbary@gmail.com
}

Garbary, David J., Nicholas M. Hill, and Anthony G. Miller. 2013. Invasion of Rosa rugosa (Rugosa Rose) into coastal plant communities of Brier Island, Nova Scotia. Canadian Field-Naturalist 127(4): 319-331.

During August and September 2010, we surveyed the entire $20.4 \mathrm{~km}$ perimeter of Brier Island, Nova Scotia, for the invasive shrub Rosa rugosa (Rugosa Rose). This island in the outer reaches of the Bay of Fundy of Nova Scotia is geographically isolated and relatively undeveloped. Our objective was to determine the extent and mechanism of the invasion of $R$. rugosa into different coastal habitats to gain insight into the potential threat to native biodiversity from the unchecked population growth of this monopolizing, rank shrub. Over 300 colonies of $R$. rugosa with mean height over $1 \mathrm{~m}$ occupied $2089 \mathrm{~m}$ of the island perimeter within $10 \mathrm{~m}$ of the top of the beach. The mean distance between colonies was about $61 \mathrm{~m}$ and the maximum distance was $1927 \mathrm{~m}$. At least 33 colonies formed almost impenetrable walls, each over $10 \mathrm{~m}$ in length, and 2 colonies occupied about $500 \mathrm{~m}^{2}$ each. Rosa rugosa had greatest density on a sand-gravel beach on which 88 colonies occupied $22 \%$ of the area and $33 \%$ of the beach margin. Exponential growth of the population (inferred from aerial photographs from 1970, 1988, and 2000) may be due to the various systems of seed dispersal. Agents include primary (American Mink, Neovison vison, and Red Squirrel, Tamiascurius hudsonicus) and secondary (an unidentified rodent) biotic dispersers. Longer distance dispersal may include Coyotes (Canis latrans), off-road vehicles and deposition of fruits by currents and waves. The main sites of seedling establishment are native habitats, such as dune grass and seashore Seaside Plantain (Plantago maritima) zones, albeit modified by this exotic rose. Dispersal of colonies contradicts a hypothesis of dispersal from human habitation along roads and tracks to the coastal habitats. We conclude that $R$. rugosa is having a significant impact on marine coastal plant communities and has the potential to dominate windswept shrub habitats on coastlines of much of Nova Scotia.

Key Words: Rosa rugosa; Rugosa Rose; coastal habitats; off-road vehicles; plant invasions; Brier Island, Nova Scotia

Rosa rugosa Thunb., Rugosa Rose, is native to northeastern Asia and has become widely distributed in both North America and Europe following escape from cultivation as an ornamental shrub and active planting to manage seashore erosion (Bruun 2005, 2006; Isermann 2007; Hill et al. 2010). The native habitat in Asia includes coastal environments (Bruun 2005). Rosa rugosa is tolerant of environmental extremes of drought, fire, salinity, uprooting, and burial by sand (e.g., Belcher 1977; Augé et al. 1990; Tsuda et al. 1999; review by Bruun 2005; Kollmann et al. 2011), providing key adaptations for its success as an invasive species.

There is extensive literature on the spread of $R$. rugosa in Europe, particularly around the Baltic Sea and the North Sea, where it has become invasive in coastal habitats and especially in sand dune systems (Fremstad 1997; Didriksen 1999; Isermann 2007; Kollmann et al. 2007; Isermann 2008a, 2008b, 2008c; Jørgensen and Kollmann 2009; Damgaard et al. 2011; Hantson et al. 2012). Less attention has been paid to R. rugosa in North America, although Bicknell (1911) provided an initial account of its invasive properties in northeastern North America based on observations in Nantucket. The species is widespread in eastern Canada (Darbyshire 2003), and Hill and Blaney (2010) suggested that $R$. rugosa is among the adventive species likely to be major invaders of coastal habitats of eastern Canada.
Fernald (1921) first described $R$. rugosa as a naturalized plant in Nova Scotia from Yarmouth County, at the southwestern corner of the province. Herbarium records and incidental field observation by the current authors show that the species is widely distributed in Nova Scotia; however, no detailed study of the species has been undertaken in seashore habitats in the province, except for a recent survey of coastal sand dune barrier beach systems facing the Gulf of St. Lawrence (Hill et al. 2010). There, $45 \%$ of 24 beach systems were colonized, and R. rugosa covered up to $8.8 \%$ of beach area.

Since the native habitat of $R$. rugosa includes coastal marine communities in addition to sand dunes (Bruun 2005), we decided to survey a defined area of Nova Scotia where rocky headlands and shrub communities predominated. Brier Island was selected because it is a discrete system that is relatively undeveloped and its shorelines are easily accessed. This island provides a microcosm of the coastal region of much of Nova Scotia and adjacent New Brunswick and New England because of its wide diversity of habitat types that include: sand and rocky shore, barachois (brackish ponds), cliffs, sheltered bays and exposed points.

Our primary objective was to evaluate the extent to which $R$. rugosa was colonizing a small island and to anticipate colonization elsewhere on this basis. In addi- 
tion to determining the extent of colonization, we investigated the differential ability of $R$. rugosa to colonize different plant communities and the potential vectors responsible for colonization events.

Given the likely colonization starting from garden plantings in Westport village, we hypothesized that a natural gradient of colony sizes and densities around the island might be reconstructed, with Westport as the origin, as per Jørgensen and Kollmann (2009).

\section{Methods}

\section{Study site}

Brier Island is an isolated island in the Bay of Fundy of Nova Scotia (Figure 1). It is about $6.9 \times 2.7 \mathrm{~km}$ in maximum dimensions, with a perimeter of about $20.4 \mathrm{~km}$ (Figure 2A). The island has a major axis running from northeast to southwest. The northwestern shore is extremely wind exposed, and the more protected eastern shore faces adjacent Long Island. The extreme tidal amplitude (regularly greater than $5 \mathrm{~m}$ ) and narrow passage between Brier Island and Long Island result in strong currents as well as high wind and wave exposure that would facilitate dispersal of fruit (hips) of R. rugosa.

Brier Island is at the southwestern tip of an extensive basaltic formation that extends for at least $200 \mathrm{~km}$ along Long Island, Digby Neck, and the North Mountain of the Annapolis River valley (Roland 1982; Davis and Browne 1996). Brier Island has a single small village, Westport, a traditional fishing community with a tourist industry based largely on whale and bird watching. There is currently little agriculture on the island, and most of the terrestrial landscape consists of coastal barrens, boreal forest (with spruces, Picea spp.; Balsam Fir, Abies balsamea (L.) Mill; and Green Alder, Alnus viridis (Chaix) de Candolle) and extensive wetlands. Most of the shoreline consists of outcrops of basaltic bedrock with large boulder fields and occasional sand or gravel beaches. The relatively undeveloped shorelines (except in Westport) consist of abandoned farmland in various stages of succession and other, more natural, habitats. These shorelines have become modified by an extensive network of trails used by off-road vehicles and coastal hikers; these trails are ideal for surveying the extent of colonization by R. rugosa.

We divided the island perimeter into 10 sections (labelled clockwise A-J), with each section representing distinctive habitat or topographic features (see Figure $2 \mathrm{~A}$ and Table 1 ) or suitable survey units. The village of Westport was considered as two sample segments: $\mathrm{J}$ represented the actual seafront with its apparently wild colonies of $R$. rugos $a$ and $\mathrm{J}$ ' included the formal plantings and roadside colonies not associated with the seashore.

\section{Historical reconstruction}

To reconstruct the timing of colonization of $R$. rugosa around the island, we used aerial photos from 1970 (1:12 000), 1988 (1:10 000), and 2001 (1:10 000) provided by Service Nova Scotia and Municipal Relations (http://www.gov.ns.ca/snsmr/land/products/air2 .asp). These were compared with images from Google Earth (2010) and our colony map from 2010.

\section{Sampling of coastal habitats}

We surveyed almost the entire $20.4 \mathrm{~km}$ coastline of Brier Island by walking along roads and coastal trails

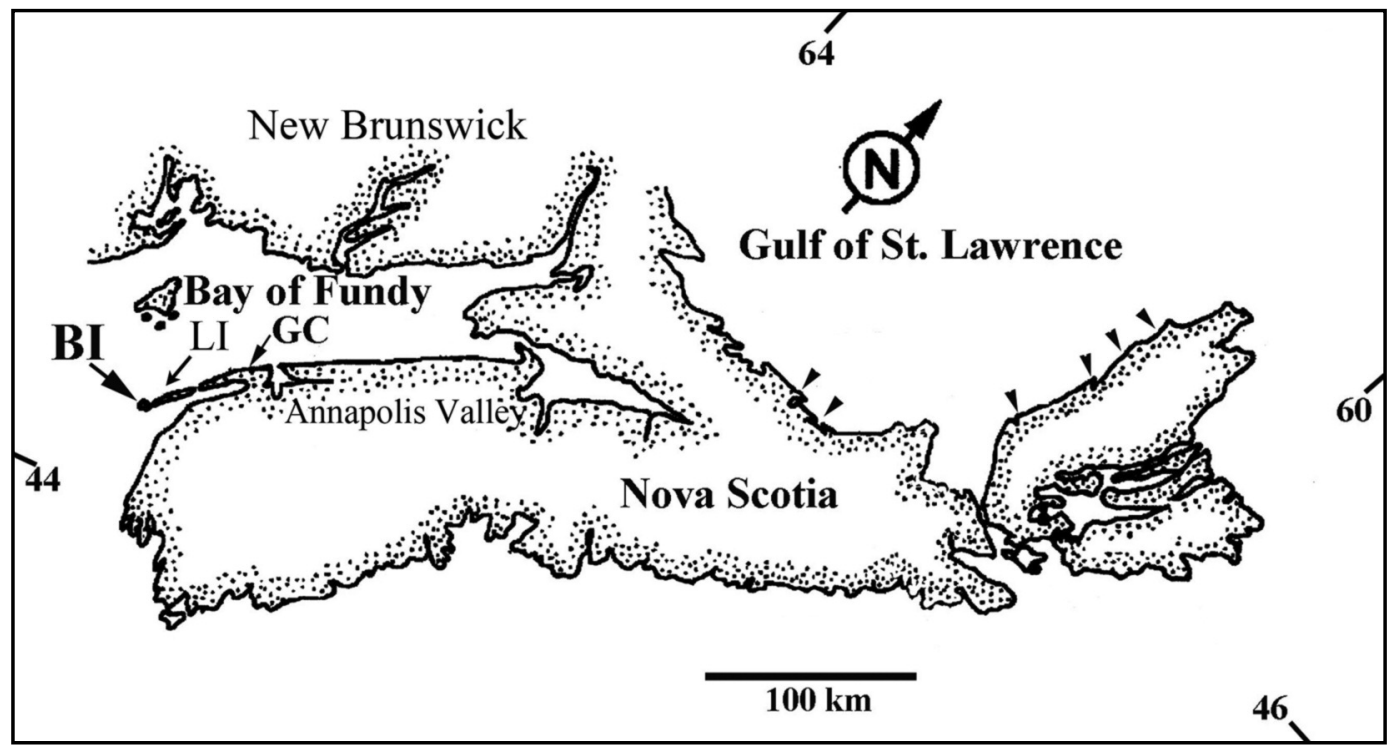

FIgURE 1. Map of Nova Scotia showing the location of Brier Island. The barrier beach/sand dune systems in the Gulf of St. Lawrence where Rosa rugosa (Rugosa Rose) has colonized (Hill et al. 2010) are marked by arrows. Abbreviations $\mathrm{BI}, \mathrm{LI}$, and GC refer to Brier Island, Long Island, and Gulliver's Cove. 

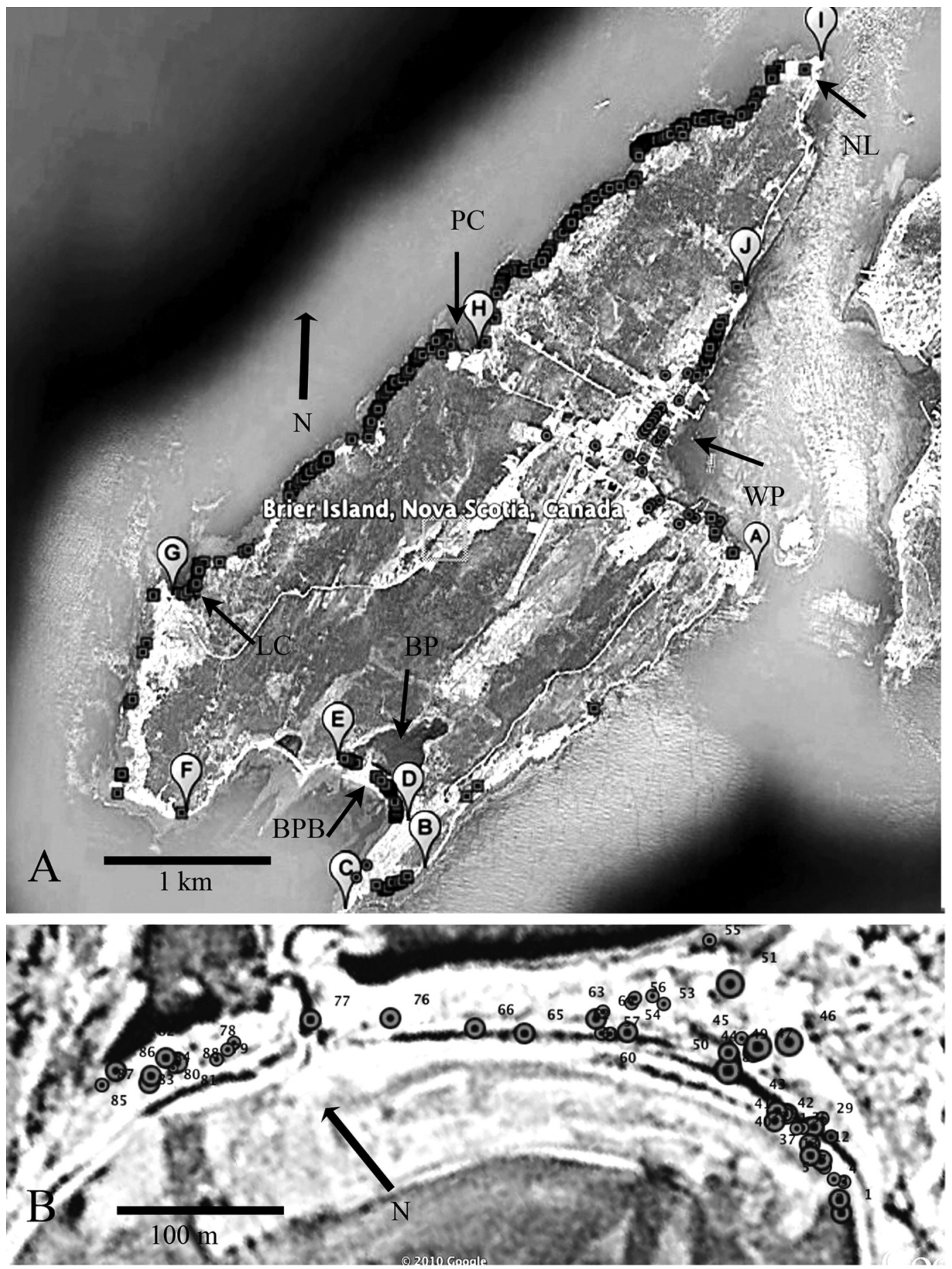

FIgURE 2. A. Image of Brier Island, Nova Scotia, from Google Earth in 2010 indicating shoreline reaches (clockwise starting at A) and locations of individual clumps of Rosa rugosa (Rugosa Rose) within $10 \mathrm{~m}$ of the top of the beach (squares) and colonies further than $10 \mathrm{~m}$ away or obviously associated with human planting (circles). Shoreline segment D (Big Pond Beach) is enlarged in B. Shoreline segments correspond to Table 1. Abbreviations PC, WP, NL, BP, BPB, and LC refer to: Peajack Cove, Westport (village), North Light, Big Pond, Big Pond Beach and Lighthouse Cove. B. Google Earth image of Big Pond Beach (shoreline segment D) with approximate locations of all colonies plotted based on area (size categories for symbols from smallest to largest: $<1 \mathrm{~m}^{2}, 1-10 \mathrm{~m}^{2}, 11-100 \mathrm{~m}^{2},>100 \mathrm{~m}^{2}$ ). 
TABLE 1. Principal habitats occupied by Rosa rugosa (Rugosa Rose) on Brier Island, Nova Scotia, in August and September 2010, conspicuous sites for seedling development, and vegetation in adjacent coastal uplands in the 10 shore reaches (see Figure $2 \mathrm{~A}$ for locations of each shoreline segment and Table 2 for characterization of the extent of colonization of each area).

\begin{tabular}{|c|c|c|c|c|}
\hline $\begin{array}{l}\text { Shoreline } \\
\text { segment }\end{array}$ & $\begin{array}{l}\text { Adjacent } \\
\text { coastal } \\
\text { upland }\end{array}$ & $\begin{array}{l}\text { Principal } \\
\text { Rosa rugosa } \\
\text { habitat }\end{array}$ & $\begin{array}{l}\text { Regeneration } \\
\text { habitat }\end{array}$ & $\begin{array}{c}\text { Occurrence of } \\
\text { Rosa rugosa } \\
\text { seedlings }(\% \text { of sites })^{1}\end{array}$ \\
\hline A & Spruce forest, old field & Rosa rugosa uncommon & N/A & \\
\hline $\mathrm{B}$ & Old field & Old field & $\begin{array}{l}\text { Off-road vehicle } \\
\text { disturbance? }\end{array}$ & Not evaluated \\
\hline $\mathrm{C}$ & Old field & Old field & $\begin{array}{l}\text { Off-road vehicle } \\
\text { disturbance? }\end{array}$ & Not evaluated \\
\hline $\mathrm{D}$ & None (lagoon) & $\begin{array}{l}\text { In sand/cobble } \\
\text { of barrier beach }\end{array}$ & $\begin{array}{l}\text { Under Rosa } \\
\text { rugosa adults }\end{array}$ & Occurrence $=55 \%$ \\
\hline $\mathrm{E}$ & $\begin{array}{l}\text { Spruce forest, Green } \\
\text { Alder thicket, steep } \\
\text { unstable cobble }\end{array}$ & Rosa rugosa absent & N/A & \\
\hline $\mathrm{F}$ & Old field & $\begin{array}{l}\text { Wrack line on cobble, } \\
\text { old field }\end{array}$ & $\begin{array}{l}\text { Off-road vehicle } \\
\text { disturbance? (episodic) }\end{array}$ & Occurrence $=0 \%$ \\
\hline G & $\begin{array}{l}\text { Spruce forest, rank } \\
\text { vegetation in seeps, } \\
\text { narrow old field }\end{array}$ & $\begin{array}{l}\text { Old field, wrack line } \\
\text { on cobble, bluffs }\end{array}$ & $\begin{array}{l}\text { Bluff crevices, salt } \\
\text { spray zone, off-road } \\
\text { vehicle disturbance }\end{array}$ & Occurrence $=6 \%$ \\
\hline $\mathrm{H}$ & $\begin{array}{l}\text { Old field, low heath, } \\
\text { bluffs }\end{array}$ & $\begin{array}{l}\text { Old field and heath, } \\
\text { salt spray zone, } \\
\text { bluffs and gullies }\end{array}$ & $\begin{array}{l}\text { Salt spray zone } \\
\text { (gravel with } \\
\text { Plantago maritima) }\end{array}$ & Occurrence $=25 \%$ \\
\hline I & $\begin{array}{l}\text { Spruce forest, Green } \\
\text { Alder thicket, old field }\end{array}$ & Rosa rugosa absent & N/A & \\
\hline $\mathrm{J}$ & $\begin{array}{l}\text { Gardens, seawall, } \\
\text { waste places }\end{array}$ & $\begin{array}{l}\text { Gardens, seawall, } \\
\text { wrack line on cobble, } \\
\text { ditches }\end{array}$ & Not evaluated & \\
\hline
\end{tabular}

$\overline{{ }^{1} \text { Seedling occurrence refers to the percentage of Rosa rugosa bushes that had R. rugosa seedlings (first- or second-year stages) }}$ within $2 \mathrm{~m}$ of their margin.

in August and September 2010. A total of about $1 \mathrm{~km}$ of shoreline was inaccessible, part in an area with high coastal cliffs where spruce forest came to the cliff edge and part in an area that was signposted as private. These areas were not surveyed, but they were partially scanned from a distance with binoculars, and no $R$. rugosa was observed.

The location of each colony of $R$. rugosa within $10 \mathrm{~m}$ of the top of the beach was noted with GPS (eTrex, Garmin, Olathe, Kansas). The length of each colony parallel to the shore, its maximum dimension perpendicular to the shore, and maximum height were measured, and the cover was estimated. While additional colonies were noted, only the largest colonies parallel to the shoreline were measured. Thus, at any one position we did not measure smaller colonies closer to or further from the seashore.

Where multiple colonies overlapped, we measured the maximum linear extent of the combined colonies and then estimated overall cover. Where colonies had clearly fused (i.e., with a mixture of red and white flowers), these were counted as one. Thus our estimate of colony numbers is an underestimate of establishment events. Furthermore, since larger colonies are typically taller, our values for maximum colony height are likely an underestimate of overall colony stature (large colonies would be given only a single height value).

The island perimeter was considered as 10 shoreline reaches. In addition to the colony census, the vegetation type associated with each reach was recorded. We used these data to determine the differential ability of $R$. rugosa to colonize different landscape forms and naturally occurring plant communities. These data informed our understanding of seedling occurrence and provided the basic description of the various reaches found in Table 1. Distance between colonies was estimated after the GPS locations of the colonies had been plotted onto an image from Google Earth (Google Inc. 2010) and the image had been enlarged. We then used the path length tool to estimate distance at a resolution of $0.1 \mathrm{~m}$.

\section{Sampling at Big Pond Cove}

In addition to mapping the perimeter of the island, we undertook more comprehensive mapping at a single site to document the ability of $R$. rugosa to spread in two dimensions over a landscape. This small area, at Big Pond Cove, was a cobble-sand beach system at the southwestern corner of the island (segment D). It was bounded on the seaward side by an extensive cobble-sand beach in the intertidal zone and on the landward side by a brackish lagoon (Big Pond). A conspic- 
uous dune system was absent, and the slightly raised ridge facing the shore was about $1 \mathrm{~m}$ in elevation above the water level in Big Pond. The system was about $600 \mathrm{~m}$ long and varied from about $50 \mathrm{~m}$ in width at the western end to about $120 \mathrm{~m}$ in width at the eastern end, where it merged into a more terrestrial landscape of Green Alder and spruce scrub.

Detailed mapping of the R. rugosa colonies was made using a hand-held GPS. Each colony was measured (length, width, maximum height), and the flower colour was recorded (pink or white). Beach area was determined from Google Earth as $32000 \mathrm{~m}^{2}$.

The seashore and beach survey included the entire population within the defined sampling spaces. Hence these are not sample estimates, but measures of the entire population. Consequently, the measure of population standard deviation is sigma (s) rather than the typical sample standard deviation (s) used to describe sample dispersion (Sokal and Rohlf 1995).

\section{Observations of seed dispersal and establishment}

Observations were made on the state of rose hips, seeds, and seedlings in populations along the island's western and southern shores (shoreline segments $D$ to $\mathrm{H}$ on Figure 2A). Basic data were needed to fill in information on the processes that may contribute to the rapid spread of this species on Brier Island. Accordingly, distance measurements were taken of detached whole hips and seeds from the nearest adult rose for 6 bushes growing on a cobble beach on the eastern shore of Lighthouse Cove (at the southern end of segment $G$ ) where the scatter of seeds showed that dispersal was well under way. This is a low-lying coast, and the inland edge of the bushes merges with rank vegetation at the edge of lagoon pools. Predation of the scattered seeds was prominent at Peajack Cove (at start of $\mathrm{H}$ on Figure 2A), and the level of predation among the scattered hips for 6 bushes was recorded. Mammal scats were encountered during the seedling survey and 6 were collected, dissected and the seeds in the scats were identified.

The terrain in the vicinity of adult bushes of $R$. rugosa was scrutinized for the presence of seedlings. The percentage of bushes with $R$. rugosa seedlings nearby was calculated for the various areas investigated (shoreline segments D through $\mathrm{H}$ ). Seedling hotspots were identified in segments $\mathrm{D}$ and $\mathrm{H}$, but for other areas where R. rugosa was common (e.g., segment $\mathrm{G}$ ) or scattered (e.g., segment F), no mechanism was discovered that might account for the generation of new $R$. rugosa clumps. For the clumps encountered in the regeneration survey, we calculated the proportion that were located beside an off-road vehicle trail.

\section{Results}

\section{Historical reconstruction}

The large colony of Rosa rugosa to the west of North Light, clearly visible on Google Earth, corresponds to an expanse of shrubbery that was present in the 2001 and 1988 aerial photographs, but was absent in 1970 . The resolution for Brier Island on Google Earth is insufficient to resolve the $R$. rugosa colonies at Big Pond Beach. What are likely R. rugosa colonies at Big Pond Beach can be distinguished in the 2001 aerial photographs, but the colonies are fewer. The large continuous expanses present in 2010 are absent in the 2001 aerial photographs. The 1988 and 1970 aerial photographs show no large vegetation on Big Pond Beach.

The aerial photographs revealed a major change in the landscape between 1970 and 2001. In 1970, there was no evidence of the network of off-road vehicle trails around much of the island perimeter. These trails were conspicuous in the 1988 aerial photographs and become successively more developed by 2001 and 2010. These trails are used by island inhabitants in the collection of wild berries (e.g., berries of the Large Cranberry, Vaccinium macrocarpon) on the coastal heathlands, Common Periwinkles (Littorina littorea) in the rocky intertidal zone, and presumably for recreation.

The large isolated colony of $R$. rugosa at the northern tip of Brier Island was $40 \mathrm{~m}$ long in 2010. By calibrating the dimensions of this colony with reference points in Google Earth, we calculated that this colony was $34.6 \mathrm{~m}$ long in 2001 and $26.2 \mathrm{~m}$ long in 1988 . Accordingly, the growth rate of this colony was $0.7 \mathrm{~m}$ year ${ }^{-1}$ between 1988 and 2001 and 0.6 m year $^{-1}$ between 2001 and 2010. If the five largest colonies in the 2001 aerial photographs of Big Pond Cove (segment D) are the same colonies as the largest ones in 2010 , colony size increased from $10 \mathrm{~m}$ (SD 5) to $31 \mathrm{~m}$ (SD 17). This gives an apparent growth rate of $2.3 \mathrm{~m}$ year $^{-1}$; however, this high rate may be the result of fusion with adjacent colonies not resolved in the 2001 aerial photograph.

\section{The perimeter of Brier Island}

Colony number and inter-colony distance: In our almost complete $20 \mathrm{~km}$ survey of the shorelines of Brier Island, we noted over 300 colonies of $R$. rugosa, which comprise $10.2 \%$ of the island perimeter (Table 2). The largest run of shoreline devoid of $R$. rugosa was $1750 \mathrm{~m}$ (shoreline segment I), where dense Alnus and Rubus (raspberry, blackberry, and dewberry) thickets occupied the top of the shoreline along a cliff. This site might represent a farm that was abandoned prior to the introduction and naturalization of $R$. rugosa. The density and height of the vegetation would have made colonization by $R$. rugosa difficult. Segment $\mathrm{C}$ had two $R$. rugosa colonies (Figure 2A), but these were over $10 \mathrm{~m}$ from the top of the beach and were not included in the perimeter enumeration.

Distance between colonies was highly skewed in favour of short distances, suggesting a clumping of colonies and secondary spread following initial colonization. The median distance between colonies was $<25 \mathrm{~m}$, with $14.5 \%$ of colonies being separated by $<5 \mathrm{~m}$ (Figure 3A). There were only 5 inter-colony gaps of $>1000 \mathrm{~m}$. 
TABLE 2. Distribution of Rosa rugosa (Rugosa Rose) around the perimeter of Brier Island, Nova Scotia, in August and September 2010, within $10 \mathrm{~m}$ of the top of the beach. See Figure 2A for areas covered in this table. Note distance between colonies is uncorrected for colony size, but is based on point GPS coordinates. Standard deviation is in parentheses.

\begin{tabular}{|c|c|c|c|c|c|}
\hline \multirow[b]{2}{*}{$\begin{array}{l}\text { Shoreline } \\
\text { segment }\end{array}$} & \multicolumn{4}{|c|}{ Rosa rugosa } & \multirow[b]{2}{*}{$\begin{array}{c}\text { Percentage of segment } \\
\text { perimeter occupied } \\
\text { by Rosa rugosa }(\%)\end{array}$} \\
\hline & $\begin{array}{l}\text { Shoreline } \\
\text { segment } \\
\text { length }(\mathrm{m})\end{array}$ & $\begin{array}{c}\text { Number of } \\
\text { colonies }\end{array}$ & $\begin{array}{c}\text { Sum of } \\
\text { colony } \\
\text { length }(\mathrm{m})\end{array}$ & $\begin{array}{l}\text { Mean distance } \\
\text { between } \\
\text { colonies }(\mathrm{m})\end{array}$ & \\
\hline $\mathrm{A}$ & 3260 & 3 & 8 & $1014(912)$ & 0.02 \\
\hline $\mathrm{B}$ & 680 & 24 & 98 & 87 (202) & 14.4 \\
\hline $\mathrm{C}$ & 770 & 0 & 0 & - & 0 \\
\hline $\mathrm{D}$ & 630 & 29 & 236 & $20(31)$ & 37.5 \\
\hline $\mathrm{E}$ & 1420 & 0 & 0 & - & 0 \\
\hline $\mathrm{F}$ & 2310 & 11 & 68 & $218(241)$ & 2.9 \\
\hline G & 3260 & 77 & 822 & $42(71)$ & 25.2 \\
\hline $\mathrm{H}$ & 3630 & 133 & 723 & $30(44)$ & 19.9 \\
\hline I & 1750 & 0 & 0 & - & 0 \\
\hline $\mathrm{J}$ & 2730 & 25 & 134 & $93(270)$ & 4.9 \\
\hline Total & 20440 & 302 & 2089 & 60.8 & 10.5 \\
\hline
\end{tabular}

The average distance between colonies was about $61 \mathrm{~m}$ (Table 2). This number is an overestimate, as it does not take colony size into account; including colony size would reduce the inter-colony distance to $54 \mathrm{~m}$. These are also conservative estimates of inter-colony distance, as we considered only colonies on a continuous line parallel to the shore, and only the largest of these were measured. Hence smaller colonies that overlapped with larger ones were not measured, and no zero values for inter-colony distances were recorded. This average also includes shoreline stretches (e.g. eastern island, segment A) where Rosa rugosa is uncommon and where large inter-colony distances (viz. $1927 \mathrm{~m}$, the island maximum from segment A) further inflate the average inter-colony calculation.

Colony length: Colony length was highly variable and ranged from less than $1 \mathrm{~m}$ to $116 \mathrm{~m}$. Over one-third of the colonies were $<3 \mathrm{~m}$ long, and about one-fifth of colonies were $>10 \mathrm{~m}$ in length (Figure 3B). Average length of colonies ranged from $2.8 \mathrm{~m}$ in segment $\mathrm{A}$ to $10.7 \mathrm{~m}$ in segment $\mathrm{G}$ (Table 3 ). Five of the segments had colony lengths on a continuum from $4.1 \mathrm{~m}$ to $6.2 \mathrm{~m}$ with differences between segment averages of $<1 \mathrm{~m}$. There were larger differences in length between segments $\mathrm{F}$ and $\mathrm{D}(1.9 \mathrm{~m})$ and between segments $\mathrm{D}$ and $\mathrm{G}(2.6 \mathrm{~m})$. Until colonies are aged, it is not possible to determine whether colony size in the different segments represents adaptations to different environments (e.g., wind exposure) or differences in time of colonization.

Colony height: The different segments had a wide range of colony heights (Figure 3C). The large histogram peak at $150-159 \mathrm{~cm}$ (approximately $1.5 \mathrm{~m}$ ) and the smaller surrounding values in Figure $3 \mathrm{C}$ are artifacts of approximating maximum height in colony interiors. Colony height in different segments ranged from $74 \mathrm{~cm}$ (SD 45) in segment $\mathrm{H}$ to $151 \mathrm{~cm}$ (SD 47) in segment J (Table 3).
The shortest colonies were in the open heathland (segments B, F, G, and H) and at the A site (Table 3). In segment $\mathrm{H}$, these short colonies were associated with an open shrub community on the portion of the island with the most wind exposure (Table 3). Other shoreline segments with open heathland were B, F, and G, where R. rugosa was conspicuously shorter than in the colonies in the village of Westport. Outside Westport, the tallest colonies occurred either on the sand beach system in segment D (note large standard deviation) or in a narrow band between the top of the shore and the start of spruce forest in segment G. In both of these segments, many colonies were over $2 \mathrm{~m}$ in height. There were few regeneration opportunities for Rosa rugosa along the sheltered but unsettled, A segment coastline $(\mathrm{n}=3$ bushes) and the mean colony height was low. There are cliffs along much of the A coastline and this area has succeeded in conifer forest and thick shrub (e.g., Wild Raisin, Viburnum nudum L.; and Speckled Alder, Alnus incana (L.) Moench).

Colony area: There was an extreme range in colony size on Brier Island. About one-third of colonies were less than $5 \mathrm{~m}^{2}$ in area, one half were under $10 \mathrm{~m}^{2}$ (Figure 3D), and a twentieth of colonies occupied over $100 \mathrm{~m}^{2}$. Other than segment A, which had only three plants, with a mean of $6.4 \mathrm{~m}^{2}$ (Table 3), the smallest colonies were found in Westport. There was little difference between the planted beds and hedges and the apparently wild colonies along the shorefront (both about $10 \mathrm{~m}^{2}$ ). The remaining segments had much larger colonies, ranging from $22.7 \mathrm{~m}^{2}$ in segment $\mathrm{B}$ to $69.5 \mathrm{~m}^{2}$ in segment G. Even when corrected for cover, segment G, with $48.1 \mathrm{~m}^{2}$, had the largest colonies. Large differences between area and area corrected for cover within a segment (Table 3 ) are based on either extensive marginal growth of established colonies or establishment of many new colonies within a general area. 

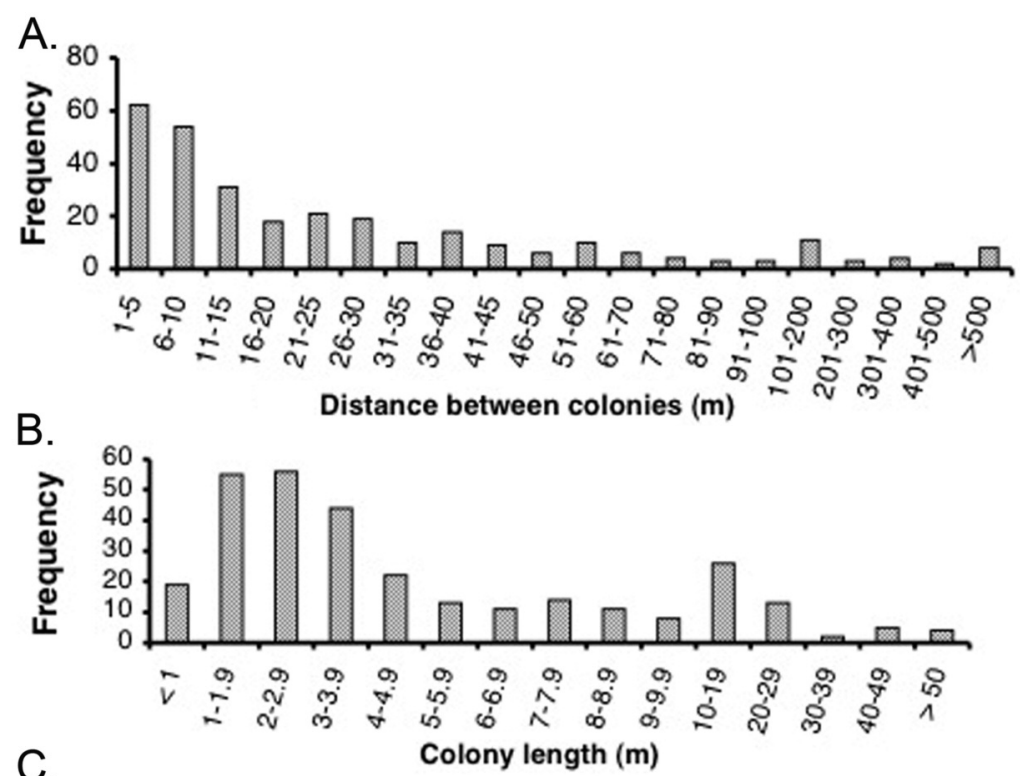

C.
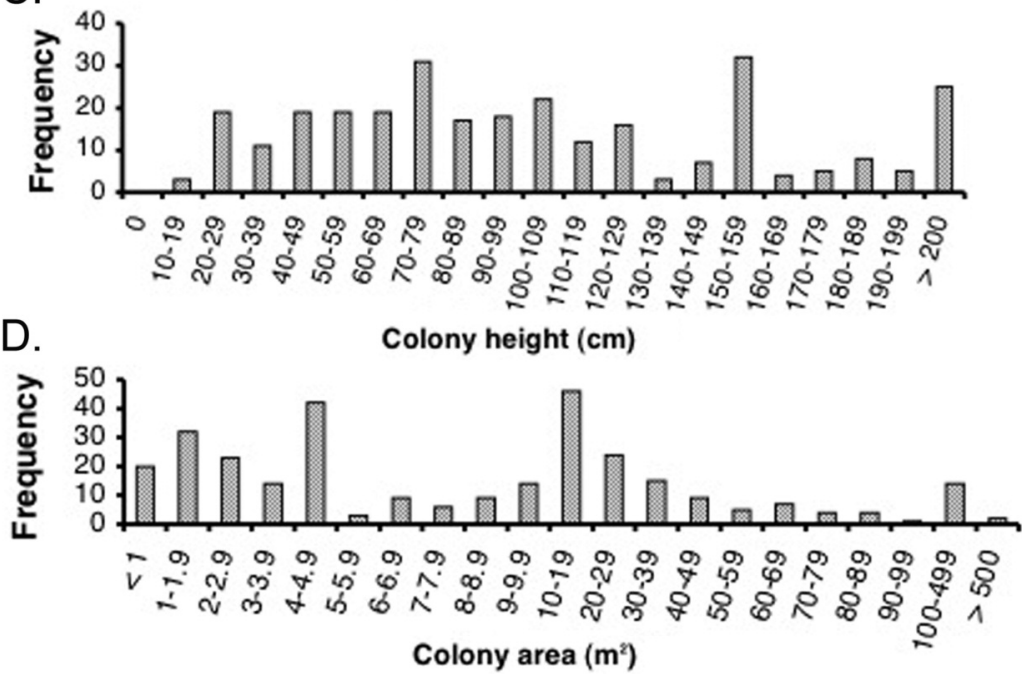

Figure 3. Morphometric analysis of Rosa rugosa (Rugosa Rose) colonies on Brier Island, Nova Scotia, in August and September 2010, indicating frequency distributions. A. Distance between colonies. B. Colony length. C. Colony height (the high frequency of heights in category 150-159 is based on approximation from margin of colony when direct measurement could not be made). D. Colony area. Note changing scale along the $x$ axis for A-D.

Westport Village (area J'): Aside from the 25 naturalized colonies of $R$. rugosa measured along the immediate shoreline of Westport (shoreline segment $\mathrm{J}$ ) (Table 2), 29 colonies were observed in the village that were associated with obvious plantings in garden beds or hedges. At $183 \mathrm{~cm}$ (SD 27), these were the tallest colonies (Table 3). Furthermore, surrounded by lawns or driveways, etc., these colonies were limited in their ability to spread; thus they all had $100 \%$ cover. Many shoreline colonies in the village (segment J) also attained an equivalent height, but the shorter average height and greater variation in heights $(151 \mathrm{~cm}, \mathrm{SD} 47)$ (Table 3) reflect continuing colonization of the shorelines. These plants on the lee side of the island were also in protected habitats beside houses and would have been under considerable care. The cultivated colonies (segment J') also had the smallest variance, likely a response to the absence of juvenile $R$. rugosa.

Big Pond Cove: The shore that was surveyed at Big Pond Cove (Figure 2B) was about $32000 \mathrm{~m}^{2}$. Other than $R$. rugosa, there was little woody vegetation. Rosa virginiana (Virginia Rose) was rare, and there were 
TABLE 3. Summary of morphometric features of colonies of Rosa rugosa in different shore reaches of Brier Island, Nova Scotia, in August and September 2010. Shoreline segments C, E, and I had no colonies of R. rugosa within the prescribed areas; J' indicates cultivated colonies in Westport village. See Table 2 for the number of colonies in each segment. Standard deviation is in parentheses.

\begin{tabular}{cccccc}
\hline \hline & \multicolumn{3}{c}{ Rosa rugosa } \\
\cline { 2 - 5 } $\begin{array}{c}\text { Shoreline } \\
\text { segment }\end{array}$ & $\begin{array}{c}\text { Mean colony } \\
\text { length } \\
(\mathrm{m})\end{array}$ & $\begin{array}{c}\text { Mean colony } \\
\text { width } \\
(\mathrm{m})\end{array}$ & $\begin{array}{c}\text { Mean colony } \\
\text { height } \\
(\mathrm{cm})\end{array}$ & $\begin{array}{c}\text { Mean colony } \\
\text { area }\left(\mathrm{m}^{2}\right)\end{array}$ & $\begin{array}{c}\text { Mean corrected } \\
\text { colony area* } \\
\left(\mathrm{m}^{2}\right)\end{array}$ \\
\hline $\mathrm{A}$ & $2.8(1.1)$ & $2.0(0.8)$ & $81(54.0)$ & $6.4(4.9)$ & $6.1(5.1)$ \\
$\mathrm{B}$ & $4.1(5.7)$ & $3.1(2.8)$ & $104(42.0)$ & $22.7(42.7)$ & $9.3(15.3)$ \\
$\mathrm{D}$ & $8.1(12.4)$ & $3.2(1.8)$ & $118(58.0)$ & $40.1(69.0)$ & $39.9(69.1)$ \\
$\mathrm{F}$ & $6.2(5.6)$ & $4.0(1.0)$ & $109(45.0)$ & $28.1(28.5)$ & $28.1(28.5)$ \\
$\mathrm{G}$ & $10.7(17.3)$ & $4.3(3.3)$ & $119(49.0)$ & $69.5(147.7)$ & $48.1(105.0)$ \\
$\mathrm{H}$ & $5.4(7.7)$ & $3.3(3.4)$ & $74(45.0)$ & $35.4(109.0)$ & $21.7(92.1)$ \\
$\mathrm{J}$ & $5.4(3.5)$ & $2.0(0.3)$ & $151(47.0)$ & $10.7(7.1)$ & $10.4(5.9)$ \\
$\mathrm{J}$ & $4.5(2.9)$ & $1.9(0.3)$ & $183(27.0)$ & $9.0(5.9)$ & $9.0(5.9)$ \\
\hline \hline
\end{tabular}

*Individual values represent colony area $\times$ cover value.

only scattered colonies of Spiraea shrubs and Ribes (currants and gooseberries), mostly toward the western end of the system. The bulk of the vegetation consisted of mixed forbs (including Elymus and Ammophila) and Rubus sp.

The 88 colonies mapped (Figure 2B) are an underestimate of the total number. Some extensive colonies had both pink and white flowers, suggesting that colonies had merged. This was more likely with pink-flowered colonies, as these outnumbered white-flowered colonies by at least $4: 1$. In addition, a few areas had hundreds of small shoots over an expanded area. These may have represented many individual plants, but for practical reasons these were considered as single colonies. Many apparently discrete colonies were also within a few metres of each other and thus may have been attached via rhizomes. The total area of the habitat with $R$. rugosa was $7100 \mathrm{~m}^{2}\left(2723 \mathrm{~m}^{2}\right.$ when the percentage cover of the colonies is considered). These values represent $22.0 \%$ and $8.5 \%$ of the surface area of the sample space, respectively.

Colonies varied from roughly $0.4 \mathrm{~m}^{2}$ to $2500 \mathrm{~m}^{2}$ (maximum of $500 \mathrm{~m}^{2}$ when area was corrected for cover), and from 0.3 to ca. $2.0 \mathrm{~m}$ in height. Mean colony area was $80.7 \mathrm{~m}^{2}$ (SD 330). Colony size was highly skewed towards smaller clumps, with a median of $5.5 \mathrm{~m}^{2}$. The two colonies with the largest overall areas were diffuse $(15 \%-80 \%$ cover $)$ and were away from the beachfront.

Of the 88 colonies, 29 (32.9\%) were within $10 \mathrm{~m}$ of the top of the beach and are included in the perimeter calculation. These beachfront colonies were significantly taller (114 cm (SD 63) vs. $89 \mathrm{~cm}$ (SD 41), $P=0.025$, Student $t$-test) than the remaining colonies on the beach.

\section{Seed dispersal and seedling establishment}

Processes that may have a bearing on the regeneration capability of $R$. rugosa were identified in the field, and some preliminary data were collected. On the western shore (shoreline segments $\mathrm{G}$ and $\mathrm{H}$ ), many rose hips had been stripped of their fleshy outside tissue. Direct observation of a Red Squirrel (Tamiasciurus hudsonicus Erxleben) holding up a rose hip next to a bush on the shoreline as well as the pattern of the stripping of the fruit from the outside of hips (consistent with Ebroch 2003), strongly suggested that squirrels might be affecting the dispersal of the rose hips. These hips were in various states of disintegration on the ground within a few metres of the putative parent plant (i.e., the nearest adult $R$. rugosa). Of the 124 scatters of seeds (in or out of remnant hip envelope) around 6 dispersing bushes at Lighthouse Cove, $47 \%$ consisted of 5 or fewer seeds, $20 \%$ had 6-10 seeds, and 19\% had 11-20 seeds. In 14\% of the seed scatters, most of the hip's seed complement was still retained $(>50 \%$ of the average 33 seeds per hip). About $44 \%$ of the seed scatters were within $1 \mathrm{~m}(100 \mathrm{~cm})$ of the parent bush and $66 \%$ were within $2 \mathrm{~m}(200 \mathrm{~cm})$ (Figure 4A). The distribution of seed scatterings away from the parent bushes conforms best to an exponential curve (Figure 4A, exponential model $\mathrm{R}^{2}=0.89$, linear model $\mathrm{R}^{2}=0.77$ ).

At Peajack Cove, there was a high incidence of predation on the seeds that were scattered around the rose bushes. The frequency of predated (observed as gnawed holes in individual seed coats) seed among the scatterings of seed varied. The seed predator, though not identified, is hypothesized to be a small vole; the pattern of rose hip remains in deer mouse, Peromyscus maniculatus Wagner, middens (Ebroch 2003) suggests this animal also influences dispersal and regeneration of this invasive rose. There were many stripped hips in the turf around the bushes, and we examined the seeds from these hips to determine the number of intact vs. predated (i.e., seed contents consumed) seeds. Sixtytwo hips from 6 bushes were surveyed, and 79\% of these had either escaped predation ( $0-5 \%$ predation) or succumbed to predation (90-100\% predation), leaving a minority with intermediate rates of seed predation. 
A

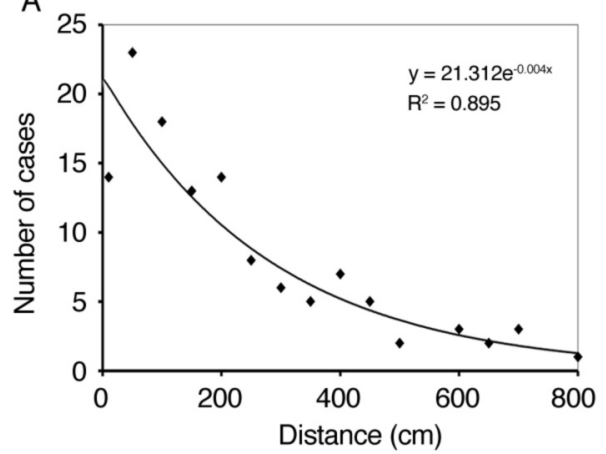

B

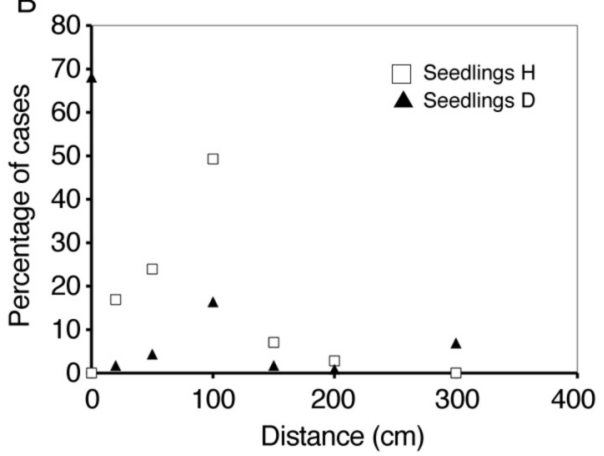

Figure 4. A. Distances of Rosa rugosa (Rugosa Rose) seed scatters (includes all cases in groupings ranging from an individual to a whole hip) from 6 bushes that were in various stages of frugivory at the start of shoreline segment $G$ on Brier Island, Nova Scotia, in 2010. Note that data follow an exponential decay curve. B. The percentage of cases of seedlings of $R$. rugosa at various distances from parent colonies in shoreline segments $\mathrm{D}$ and $\mathrm{H}$. Note that seedlings (e.g. at $\mathrm{H}$ ) inside the margin of the parent bush are assigned to the zero distance class.

Seeds of Rosa rugosa were also observed among scats discovered along the coast during the search for seedlings and observations of dispersed hips. Of the 6 scats collected, 3 were from American Mink (Neovison vison, Schreber) and 3 belonged to a larger mammal, possibly a Coyote (Canis latrans, Say). From the mink scats, seed of Bayberry (Morella pensylvanica, (Mirb.) Kartesz, in 2 scats), blackberry (Rubus sp. in 2 scats), Black Crowberry (Empetrum nigrum L. in 1 scat), and $R$. rugosa (in 2 scats) were observed. Bayberry (in 2 scats), blackberry (1 scat) and R. rugosa (in 1 scat) were also observed in the larger mammal scat.

The frequency of colonies with associated seedlings (inspection conducted within $2 \mathrm{~m}$ of the margins of the parent bushes) was low (5\%) in all shoreline segments, with the exception of segments $\mathrm{D}$ and $\mathrm{H}$, where seedling occurrence frequencies (percentage of R. rugosa bushes with associated seedlings) were $55 \%$ and $25 \%$, respectively.

Seedlings in segment $\mathrm{D}$ were established in sand at the margin of the parent clumps (Figure 4B). Although the average distance between seedlings and parents was $38 \mathrm{~cm}$ (SD 65) $(n=116), 63 \%$ of these seedlings were "nursed" under the margin of the parent bush. The average value is artificially inflated, since all cases of "nursing" were assigned a zero distance to the parent margin. Seedling density around 16 R. rugosa bushes examined, expressed as a function of bush area, gave a density of 1.8 seedlings per $\mathrm{m}^{2}$ of area occupied by $R$. rugosa in this sand dune habitat.

In segment $\mathrm{H}$, seedlings were not observed underneath parent plants (Figure 4B). The average distance between seedlings and parents was $69 \mathrm{~cm}$ (SD 27) $(n$ $=71$ ), approximately half the distance between the detached hips in this segment and the putative parents (124 cm, SD 121, $n=102)$. Seedlings in segment $\mathrm{H}$ were all associated with low biomass vegetation at the maritime/terrestrial transition; in all cases, seedlings were associated with Plantago maritima (Seaside Plantain) and basaltic gravel.

The distribution of $R$. rugosa on Brier Island extends to areas that were surveyed for seedlings but which revealed very few (Figure 2A) (for 13 and 32 surveyed bushes in segments $\mathrm{F}$ and $\mathrm{G}$, seedlings occurred at 0 and $6 \%$ of bushes, respectively). These segments did not have much of the two seedling nursery habitat types identified in segments D and H (Ammophila breviligulata, American Beachgrass) and sand in segment $\mathrm{D}$ and basalt gravel dominated by P. maritima in segment $\mathrm{H}$ ). The non-wooded habitat of segments $F$ and $G$ was either more closed (e.g., old field turf of segment F) or the vegetation was more rank and vigorous (e.g., tops of cobble beaches and seeps in segment G). In these areas without natural seedling nurseries, there was an association between the existing clumps of $R$. rugosa and off-road vehicle trails (13\% and $25 \%$ of $R$. rugosa clumps surveyed in segments F and G, respectively, were beside off-road vehicle trails) not noted in the other segments.

\section{Discussion}

Contrary to our expectations, the study results from Brier Island clearly dispute the garden infection model suggested for Rosa rugosa (Jørgensen and Kollmann 2009; Hill et al. 2010) and the classic account of Berberis vulgaris (Common Barberry) (Stakman et al. 1927). We found no evidence that $R$. rugosa gradually spread from Westport village around the coastline to surround the island. Indeed, in the two stretches of shoreline immediately adjacent to the village, $R$. rugosa was either absent (shoreline segment $\mathrm{H}$ ) or had low density, with a large gap between the village and the first clump, i.e., $1.9 \mathrm{~km}$ (segment A). Furthermore, the occurrence of both pink- and white-flowered colonies scattered around the island suggests multiple colonizations based on stochastic events. 
Jørgensen and Kollmann (2009) suggested that colonization of dunes in Europe was associated with roads and tracks. On Brier Island, the roadsides of the three main roads to the northern, western, and southern corners of the island were devoid of $R$. rugosa for distances of over 1,2, and $3 \mathrm{~km}$ from the respective shores. Hence colonization from the community via gradual spread along these routes is regarded as unlikely.

Having falsified our original hypothesis, we suggest two alternate hypotheses to explain how R. rugosa dispersed from the village to distant shorelines around Brier Island: animal vectors and water dispersal mediated by tides, waves, and currents.

Once colonization of the western shore had occurred (i.e., reached segments $\mathrm{G}$ and $\mathrm{H}$ ), we suggest that offroad vehicles provided a dispersal mechanism by trapping and transporting seeds within the coarse treads of tires. We have no experimental data to support this, but the densest clumps on Brier Island (other than in segment $\mathrm{D}$ ) were adjacent to seaside trails primarily used by off-road vehicles (e.g., segments $\mathrm{G}$ and $\mathrm{H}$ ). Where these trails departed from an immediate seaside path, colony density was greatly reduced (i.e., segment F).

Rosa rugosa was introduced to Nova Scotia as an ornamental shrub in residential areas. By the 1920s, this species had become naturalized, and Fernald (1921) reported it as common in Yarmouth County. We have no formal record of the introduction of the species on Brier Island, but Westport has numerous small plantings and hedges around dwellings that are likely of long standing. These likely were the source of the wild populations described in this paper. The large number of small plants and the absence of conspicuous dead plants are consistent with an ongoing colonization facilitated by large colonies with their attendant fecundity. The observations of the establishment of seedlings suggest that mass colonization of the shorelines is underway.

Regional climate change and sea level rise may be facilitating the spread of $R$. rugosa. While all seaside plants must have some salt tolerance, $R$. rugosa is particularly salt tolerant (e.g., Dirr 1978). This was evident on Brier Island, where colonies were also present in the cobble at the tops of beaches, even closer to the sea than other shrub species. Once $R$. rugosa becomes established, its greater height and dense shoots allow it to exclude other shrubs. On sand dunes, $R$. rugosa may colonize the dune slacks (e.g., Hill et al. 2010), but $R$. rugosa is typically on the seaward side of its congener, the native $R$. virginiana.

While dispersal of $R$. rugosa by birds has been observed elsewhere in offshore islands in the Bay of Fundy (Rajakaruna et al. 2009) and birds are a likely vector on Brier Island which has a large population of Herring Gulls (Larus argentatus, Pontoppidan), we have evidence that a suite of native mammals effect and affect the dispersal of this invasive rose. From scat dissection, we know that two mammals, the American
Mink and a larger animal (possibly a Coyote), ingest the fleshy rose hip tissue and whole seeds. The Red Squirrel, in contrast, removes the hips from bushes, strips the fruit from the hip, consuming the fruit, and then discards the stripped hip. Finally, these stripped, discarded hips are predated - in situ it would appearat an unknown final efficiency rate, by a small rodent, possibly by Deer Mice (see Ebroch 2003).

Rose hips that are consumed by American Mink would be dispersed away from the source bush but would likely remain in the headland habitat. American Mink have been documented as a major consumer of another seaside fruit, Empetrum nigrum L. (Black Crowberry) (Hill et al. 2012), whose fruit matures much earlier than Rosa. The island has had a population of Coyotes since the 1980s and fruit can make up a large part of their diet (Quinn 1997). This putative disperser would tend to deposit scats along the the same paths and trails (see Dodge and Kashian 2013) that are frequented by the off-road vehicle. In contrast, there appears to be no endozoochory of Rosa seed taken by the Red Squirrel. All the scattered rose hips dispersed in segments $\mathrm{G}$ and $\mathrm{H}$ had the fleshy fruit stripped from the hip. Some of the hips still attached to the bushes showed selective eating of the fleshy part of the fruit and avoidance of the seeds. A Red Squirrel with a stripped hip in its paws was observed in segment $\mathrm{G}$ by $\mathrm{NMH}$, consistent with the distribution of seeds scattered around parent bushes along the western shore of Brier Island (i.e., data from segment $\mathrm{H}$ ). We suspect that dispersal of Rosa by Red Squirrels is the first stage leading to secondary dispersal processes that may be as significant as the primary dispersal process. We documented variation in the percentage of seeds that were predated by a secondary disperser whose activity fits the known pattern of rose hip utilization by the Deer Mouse (Ebroch 2003). It is likely that much of the mechanical disruption of discarded hips is brought about by this seed predator. We do not yet understand the interaction between the primary disperser (Red Squirrel) and this seed predator. The seed dispersal shadow generated by the Red Squirrel was fitted by a negative exponential regression, however, this curve has a short tail and seed scatters were not found more than 8 metres from the parent bush. Documenting how the secondary disperser might extend the tail of this seed shadow (see Nathan and Muller-Landau 2000) in this invasive rose would advance our understanding of the Rosa rugosa colonization and invasion mechanism.

At the population level, there are advantages to a scatter of seed. In some cases, all seeds in a small group will be consumed or will germinate in unsuitable substrate; in other cases, a few escape consumption and are brought to a good seed bed. Such a seed bed could be the unvegetated muddy flat of an off-road vehicle trail. We noted in segments F and G that natural seedling nurseries were rare, but that $R$. rugosa bushes had 
a strong association with off-road vehicle trails. Could off-road vehicles be causing the requisite disturbance to allow for seedlings to become established in old fields and in rank vegetation? It is conceivable that, once off-road vehicle trails have been established, offroad vehicles are the dispersal agents for the next generation of seedlings.

Given the concerns about the secondary dispersal role played by farm machinery and other vehicles in the spread of weeds and invasive exotic species (Clifford 1959; Lonsdale and Lane 1994; Garnier et al. 2008), we should be investigating this potential in the off-road vehicle. These vehicles frequently create disturbed seed beds in otherwise closed vegetation throughout North America. Logically, they must also move a fraction of the soils and propagules that they disturb.

On Brier Island, the population of R. rugosa has expanded as a result of both natural and anthropogenic factors. This exotic plant meets a strict definition of an invasive plant as "an exotic species regenerating in the wild in sufficient numbers to influence the dynamics of native plant communities" (Hill and Blaney 2010). Hence it is more than merely a reflection of the anthropogenic disturbance footprint (e.g., Jenkins and Pimm 2003). The population on Brier Island has native seed dispersers that deliver it to seedling regeneration niches in native habitats (sand in American Beachgrass dune, gravel in seashore Seaside Plantain zone), where natural disturbances maintain a supply of gaps where seedlings can become established. In the absence of anthropogenic activity, seedlings would continue to sprout on sand dunes, nursed by or in the lee of adult bushes, and in crumbling basalt at the terrestrial/marine interface. These areas could become the realized niche of $R$. rugosa in the absence of anthropogenic process and disturbance. In the meantime, we suggest that a mixture of human and natural processes and disturbance will continue to encourage the spread of this invasive.

Given the current state of colonization of Brier Island, it is easy to raise the spectre of virtually the entire island being ringed by $R$. rugosa. We observed no evidence of dieback or either landscape or competitive interactions that would constrain further growth. Other than areas where wetlands, dense Green Alder shrubbery or coniferous woodland occurred at the limits of terrestrial vegetation along the shore, or in areas of cliffs, all substrate and vegetation types were colonized by $R$. rugosa.

Kollmann et al. (2009) showed a clonal spread rate of $0.42 \mathrm{~m}$ year $^{-1}$ on coastal dunes in Europe. This is the equivalent of one successful shoot per clone based on rhizome spread and emergence of a new shoot. The growth rate that we determined in one large colony on exposed heathland was $0.65 \mathrm{~m}_{\text {year }}^{-1}$ over a 21 -year period. The higher growth rate projected over 9 years in segment $\mathrm{D}$ of $2.3 \mathrm{~m}^{\text {year }}{ }^{-1}$ may be an exaggeration because of the lack of competition from other woody plants in the beach habitat.

Relative to our data, the growth rate of $0.42 \mathrm{~m} \mathrm{year}^{-1}$ observed by Kollmann et al. (2009) provides a conservative estimate for modeling colony spread. Accordingly, the 300 coastal colonies that we mapped would produce an extension of colony length parallel to the shore of about $120 \mathrm{~m}$ year $^{-1}$ from existing colonies. Extrapolating this rate to 2020 results in an increase of $1200 \mathrm{~m}$ that would encompass $16 \%$ of the island perimeter. This is without the addition of new colonies. If new colonies become established at $5 \%$ per year (i.e., 15 new colonies in 2011), after 10 years the island would have almost 500 colonies, and these colonies would have resulted in an additional $400 \mathrm{~m}$ of the perimeter being occupied by $R$. rugosa. Accordingly, by $2020,18 \%$ of the island perimeter would be occupied by $R$. rugosa. Since most colonies are concentrated in about two-thirds of the island, this would represent a dramatic change in the coastal vegetation on the shores facing the Bay of Fundy. An exponential modeling of colony increase would result in even more dramatic changes.

Brier Island is representative of the coastline of much of Nova Scotia. This is particularly true of the headlands of the numerous peninsulas of Nova Scotia that extend into the Atlantic Ocean and the numerous offshore islands along the Atlantic coast (e.g., Hill et al. 2012). Consequently, we conclude that $R$. rugosa represents a serious threat to native plant communities on windswept coastal headlands and offshore islands of the region. We encountered a diversity of native herbs and shrubs, including those that are uncommon and of small stature (e.g., Knotted Pearlwort, Sagina nodosa, (L.) Fenzl. and Roseroot, Rhodiola rosea L.) along the coast of Brier Island. In contrast, we consistently have observed a dearth of diversity under the bushes of $R$. rugosa. This exotic rose is so abundant that it has become part of the economic botany (for jams and wine) of this area; clearly, there is a need to assess its impact on coastal biodiversity.

Bruun (2006) outlined potential strategies for biological control for $R$. rugosa, and biological control must be considered as a potential option to limit the spread of the species and its impact on native biota. Hill et al. (2012) suggested a series of management strategies for the preservation of coastal Empetrum nigrum L. heathlands. Management of R. rugosa may become a critical part of this strategy.

\section{Acknowledgements}

We thank Dolna Garbary for field assistance and Stephen Darbyshire for historical information on Rosa rugosa in eastern North America. Katelyn White provided assistance with preparation of figures. This work was supported by grants from the Natural Sciences and Engineering Research Council of Canada to DJG. 


\section{Literature Cited}

Augé, R. M., A. J. W. Stodola, and D. M. Gealy. 1990. Turgor maintenance in Rosa rugosa grown at three levels of nitrogen and subjected to drought. Journal of Environmental Horticulture 8: 108-112.

Belcher, C. R. 1977. Effect of sand cover on survival and vigor of Rosa rugosa Thunb. International Journal of Biometeorology 21: 276-280.

Bicknell, E. P. 1911. The ferns and flowering plants of Nantucket, VIII. Bulletin of the Torrey Botanical Club 38: 447-460.

Bruun, H. H. 2005. Biological flora of the British Isles. Rosa rugosa Thunb. ex. Murray. Journal of Ecology 93: 441470.

Bruun, H. H. 2006. Prospects for biocontrol of invasive Rosa rugosa. BioControl 51: 141-181.

Clifford, H. T. 1959. Seed dispersal by motor vehicles. Journal of Ecology 47: 311-315.

Damgaard, C., B. Nygaard, R. Ejrnaes, and J. Kollmann. 2011. State-space modeling indicates rapid invasion of an alien shrub in coastal dunes. Journal of Coastal Research 27: 595-599.

Darbyshire, S. J. 2003. Inventory of Canadian Agricultural Weeds. Agriculture and Agri-Food Canada, Ottawa, Ontario.

Davis, D. S., and S. Browne. 1996. The Natural History of Nova Scotia. Volume One, Topics and Habitats. Nimbus and Nova Scotia Museum, Halifax, Nova Scotia.

Didriksen, R. 1999. Hybenrosen — Et problem i kystnære naturtyper [Hip rose - a problem in coastal habitats]. Skoven 31: 237-239. (In Danish).

Dirr, M. A. 1978. Tolerance of seven woody ornamentals to soil-applied sodium chloride. Journal of Arboriculture 4: 162-165.

Dodge, W. B., and D. M. Kashian. 2013. Recent distribution of coyotes across an urban landscape in southeastern Michigan. Journal of Fish and Wildlife Management 4: 9 pages. doi: 10.3996/062013-JFWM-040.

Ebroch, M. 2003. Mammal tracks and sign. Stackpole Books, Mechanicsburg, Pennsylvania.

Fernald, M. L. 1921. The Gray Herbarium expedition to Nova Scotia, 1920. Rhodora 23: 257-278.

Fremstad, E. 1997. Fremmede planter i Norge. Rynkerose - Rosa rugosa (Alien plants in Norway. Japanese Rose Rosa rugosa). Blyttia 55: 115-121. (In Norwegian).

Garnier, A., S. Pivard, and J. Lecomte. 2008. Measuring and modelling anthropogenic secondary seed dispersal along roadverges for feral oilseed rape. Basic and Applied Ecology 9: 533-541. doi:10,1016/j.baac.2007.08.014.

Google Inc. 2010. Google Earth (Version 5.2.1.1558) (Software). Available from: http://www.google.com/earth/down load/ge/agree.html.

Hantson, W., Koistra, L., and P. A. Slim. 2012. Mapping invasive woody species in coastal dunes in the Netherlands: a remote sensing approach using LIDAR and highresolution aerial mapping. Applied Vegetation Science 15: $536-547$.

Hill, N. M., and C. S. Blaney. 2010. Exotic and invasive vascular plants of the Atlantic Maritime ecozone. Pages 215232 in Assessment of Species Diversity in the Atlantic Maritime Ecozone. Edited by D. F. McAlpine and I. M. Smith. NRC Research Press, Ottawa, Ontario.

Hill, N. M., L. Beveridge, A. Flynn, and D. J. Garbary. 2010. Rosa rugosa Thunb. as an invader of coastal sand dunes of Cape Breton Island and mainland of Nova Scotia. Canadian Field-Naturalist 124: 151-158.

Hill, N. M., S. P. Vander Kloet, and D. J. Garbary. 2012. The regeneration ecology of Empetrum nigrum, the black crowberry, on coastal heathland in Nova Scotia. Botany 90: 379-392.

Isermann, M. 2007. Impact of Rosa rugosa on dune ecosystems at the German North Sea coast - in comparison with Hippophaë rhamnoides. Pages 23-28 in Rynket rose (Rosa rugosa) i Danmark. I. Edited by I. Weidema, H. P. Ravn, and $\mathrm{P}$. Vestergaard. Rapport fra workshop på Biologisk Institut, Københavns Universitet, 5-6 september 2006. Biologisk Institut, Københavns Universitet, Skov- og Landskab samt Skov- og Naturstyrelsen, København, Denmark.

Isermann, M. 2008a. Expansion of Rosa rugosa and Hippophaё rhamnoides in coastal grey dunes: effects at different spatial scales. Flora 203: 273-280.

Isermann, M. 2008b. Classification and habitat characteristics of plant communities invaded by the non-native Rosa rugosa Thunb. in NW Europe. Phytocoenologia: Journal of Vegetation Ecology 38: 133-150.

Isermann, M. 2008c. Effects of Rosa rugosa invasion in different coastal dune vegetation types. Pages 289-306 in Plant Invasions: Human Perception, Ecological Impacts and Management. Edited by J. H. Brock, G. Brundu, L. Child, C. C. Daehler and P. Pysek. Backhuys, Leiden, The Netherlands.

Jenkins, C. N., and S. L. Pimm. 2003. How big is the global weed patch? Annals of the Missouri Botanical Garden 90: $172-178$

Jørgensen, R. H., and J. Kollmann. 2009. Invasion of coastal dunes by the alien shrub Rosa rugosa is associated with roads, tracks and houses. Flora 204: 289-297.

Kollmann, J., K. Brink-Jensen, S. I. Frandsen, and M. K. Hansen. 2011. Uprooting and burial of invasive alien plants: a new tool in coastal restoration? Restoration Ecology 19: 371-378.

Kollmann, J., L. Frederiksen, P. Vestergaard, and H. H. Bruun. 2007. Limiting factors for seedling emergence and establishment of the invasive non-native Rosa rugosa in a coastal dune system. Biological Invasions 9: 31-42.

Kollmann, J., R. H. Jorgensen, J. Roelsgaard, and H. Skov-Petersen. 2009. Establishment and clonal spread of the alien shrub Rosa rugosa in coastal dunes: a method for reconstructing and predicting invasion patterns. Landscape and Urban Planning 93: 194-200.

Lonsdale, W. M., and A. M. Lane. 1994. Tourist vehicles as vectors of weed seed in Kakadu National Park, northern Australia. Biological Conservation 69: 277-283.

Nathan, R., and H. C. Muller-Landau. 2000. Spatial patterns of seed dispersal, their determination and consequences for recruitment. Trends in Ecology and Evolution 15: 278-285.

Quinn, T. 1997. Coyote (Canis latrans) food habits in three urban habitat types of western Washington. Northwest Science 71: 3-5.

Rajakaruna, N., N. Pope, J. Perez-Orozco, and T. B. Harris. 2009. Ornithocoprophilous plants of Mount Desert Rock, a remote bird-nesting island in the Gulf of Maine, USA. Rhodora 111: 417-447. 
Roland, A. E. 1982. Geological background and physiography of Nova Scotia. Nova Scotian Institute of Science, Halifax, Nova Scotia.

Sokal, R. R., and F. J. Rohlf. 1995. Biometry: The principles and practice of statistics in biological research. Freeman, New York.

Stakman, E. C., F. E. Kempton, and D. Hutton. 1927. The common barberry and black stem rust. U.S. Department of Agriculture Farmers Bulletin No. 1544. 28 pages.
Tsuda, S., H. Fujita, and K. Nishisaka. 1999. Resprouting behavior of Rosa rugosa Thunb. after an experimental burning in Koshimizu Nature Reserve, Hokkaido, Japan. Actinia [Bulletin of the Manazuru Marine Laboratory, Yokohama National University] 12: 113-121 (In Japanese).

Received 17 July 2013

Accepted 6 September 2013 